\title{
Formulasi Strategi Perbaikan Kinerja Perusahaan Properti Pasca Akuisisi (Studi Kasus: PT XYZ)
}

\author{
Strategic Formulation for Improving Property Company Performance after \\ Acquisition (Case Study: PT XYZ)
}

\author{
Mufrad Azmadahadid ${ }^{1 *}$, Lukman Mohammad Baga², Setiadi Djohar ${ }^{3}$ \\ ${ }^{1}$ Sekolah Bisnis, Institut Pertanian Bogor, Jl. Raya Pajajaran, Bogor 16151 \\ ${ }^{2}$ Departemen Agribisnis, Fakultas Ekonomi dan Manajemen, Jl. Kamper Kampus IPB Dramaga, Bogor 16680 \\ ${ }^{3}$ Sekolah Tinggi Manajemen PPM, Jl. Menteng Raya No 9-19, DKI Jakarta 10340
}

\begin{abstract}
$P T X Y Z$ is one of property companies that involved in apartment and condotel business in Yogyakarta. At present, PT XYZ had decreased in revenue due to decreased in unit sales and delinquent payments by existing customers. These problems made the company's performance decrease so the company sold 38 percent of its shares to PT ADP and PT TBR. Together with the new management composition, the company strives to improve its performance. Therefore, a strategy formulation is needed to make the company performance being improved again. Interviews were conducted with informants selected by purposive sampling to identify company's internal and external strategic issues. The IFE matrix (Internal Factor Evaluation) and EFE matrix (External Factor Evaluation) are used to evaluate company's internal and external conditions. SWOT matrix (Strength, Weaknesses, Opportunities, and Threat) is used to find alternative strategies to improve company performance. There are five alternative strategies to improve company performance after acquisition, namely: (1) rebranding the names of apartments and condotels; (2) increase promotion and sales activities; (3) improve good relationship with consumers; (4) make value added for the apartments; (5) recruiting experienced sales employees.
\end{abstract}

Keywords: EFE matrix, IFE matrix, Performance improvement strategies, , SWOT matrix.

\begin{abstract}
ABSTRAK
PT XYZ adalah salah satu perusahaan properti yang bergerak dalam bisnis apartemen dan kondotel di Yogyakarta. Saat ini PT XYZ mengalami penurunan pendapatan akibat menurunnya penjualan unit serta menunggaknya pembayaran cicilan oleh konsumen lama. Permasalahan tersebut membuat menurunnya kinerja perusahaan sehingga perusahaan menjual 38 persen sahamnya kepada PT ADP dan PT TBR. Bersama komposisi manajemen yang baru, perusahaan berusaha untuk memperbaiki kinerjanya. Oleh karena itu, diperlukan suatu formulasi strategi yang dapat membuat kinerja perusahaan kembali membaik. Dilakukan wawancara terhadap informan yang dipilih secara purposive sampling untuk mengidentifikasi isu strategik internal dan eksternal perusahaan. Matriks IFE (Internal Factor Evaluation) dan matriks EFE (External Factor Evaluation) digunakan untuk mengevaluasi kondisi internal dan eksternal perusahaan. Matriks SWOT (Strength, Weaknesses, Opportunities, and Threat) digunakan untuk mencari alternatif strategi perbaikan kinerja perusahaan. Diperoleh lima alternatif strategi untuk memperbaiki kinerja perusahaan pasca akuisisi, yaitu: (1) rebranding nama apartemen dan kondotel; (2) meningkatkan aktivitas promosi dan penjualan; (3) meningkatkan hubungan baik dengan konsumen; (4) membuat nilai tambah apartemen yang dijual; (5) merekrut karyawan sales berpengalaman.
\end{abstract}

Kata Kunci: matriks EFE, matriks IFE, matriks SWOT, Strategi perbaikan kinerja.

\footnotetext{
*Corresponding author

Alamat e-mail: mufrad.itt@gmail.com
} 


\section{PENDAHULUAN}

Daerah Istimewa Yogyakarta (DIY) merupakan salah satu provinsi yang memiliki pertumbuhan jumlah penduduk yang terus meningkat di setiap tahunnya. Data dari Badan Pusat Statistik (BPS) pada tahun 2017 tentang jumlah penduduk di provinsi Daerah Istimewa Yogyakarta (DIY) pada tahun 2012-2016 dapat dilihat pada Gambar 1.

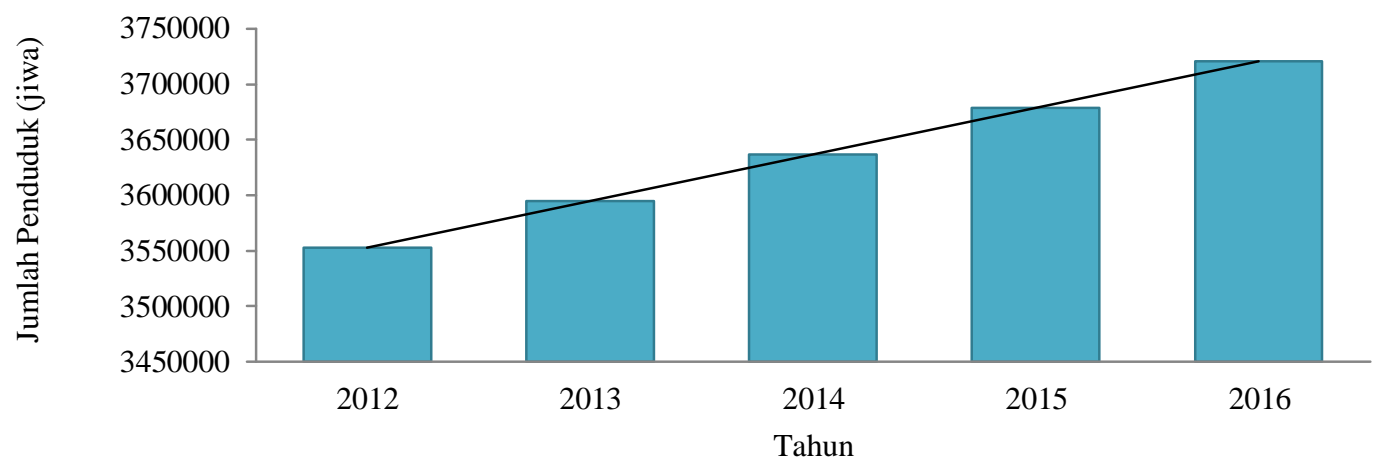

Gambar 1. Grafik Pertumbuhan Penduduk Provinsi DIY 2012-2016 Sumber: BPS DIY (2017)

Meningkatnya jumlah penduduk disetiap tahunnya membuat kebutuhan akan tempat tinggal meningkat pula. Namun keterbatasan lahan untuk tempat tinggal dan kenaikan harga selalu menjadi permasalahan di kota-kota besar yang ada di Indonesia termasuk Yogyakarta. Tren pembangunan hunian vertikal baik apartemen maupun rumah susun dinilai sebagai suatu tuntutan atas hunian di perkotaan (Devi, 2012).

Faktor tersebut tentu menjadi dorongan bagi para pelaku usaha untuk berkecimpung dalam bisnis properti terutama dalam segmen hunian vertikal atau apartemen. PT XYZ adalah salah satu contoh perusahaan yang tertarik dalam bisnis properti tersebut. PT XYZ bergerak dalam pengembangan apartemen dan kondotel di Provinsi DIY.

Ditengah berkembangnya bisnis properti terutama di pengembangan apartemen dan kondotel, PT XYZ saat ini sedang mengalami penurunan pendapatan. Penurunan pendapatan tersebut diakibatkan menurunnya penjualan unit apartemen maupun kondotel serta menunggaknya pembayaran cicilan oleh konsumen lama. Menurunnya pendapatan PT XYZ dapat dilihat pada Gambar 2.

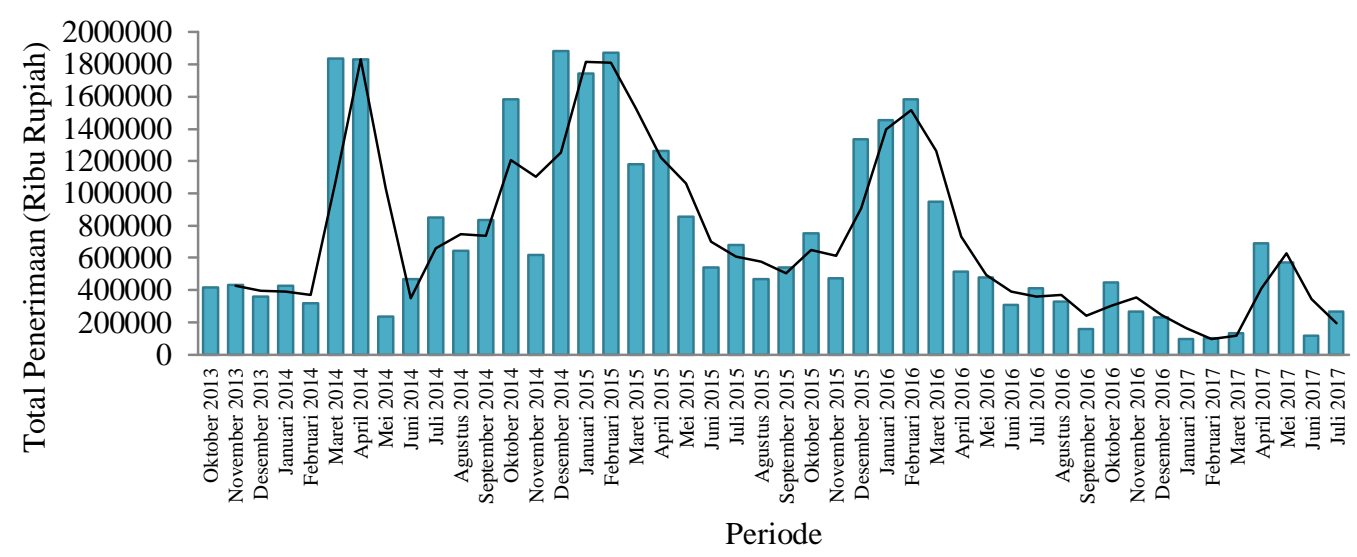

Gambar 2. Grafik Pendapatan PT XYZ Oktober 2013 - Juli 2017

Sumber: Data Internal Perusahaan, Diolah

Berbagai permasalahan tersebut mengakibatkan menurunnya kinerja perusahaan. Salah satu strategi yang dilakukan PT XYZ adalah strategi akuisisi. Menurut Suryati (2010), akuisisi 
dapat meningkatkan daya saing strategis jika perusahaan yang dipilih melalui analisis yang hatihati dan terperinci. PT XYZ pada bulan November 2017 menjual total 38 persen sahamnya kepada PT ADP dan PT TBR agar pengembangan apartemen dan kondotel tetap dapat berjalan sesuai rencana. Setelah proses akuisisi tersebut, PT XYZ dihadapkan dengan tantangan baru. Perubahan struktur manajemen membuat strategi perusahaan kedepan akan ikut berubah pula. Menurut Hashim (2016), strategi perusahaan dikembangkan melalui pendekatan strategis yang berbeda. Penyusunan strategi untuk perbaikan kinerja perusahaan diperlukan agar perusahaan dapat kembali mendapatkan kepercayaan dari konsumen sehingga perusahaan dapat bertahan dan bersaing.

Penelitian-penelitian yang terkait dengan formulasi strategi pada perusahaan properti telah dilakukan oleh beberapa peneliti, diataranya adalah Wulandari et al. (2017) yang melakukan penelitian guna meningkatkan kinerja perusahaan properti Elang Group, dengan menggunakan analisis SWOT. Hasil penelitian menghasilkan empat alternatif strategi yaitu: (1) melakukan program marketing campaign yang sistematis; (2) membangun aliansi strategis dengan perusahaan pengembang lain; (3) membuat sistem costumer relationship management yang prima; (4) merancang sistem manajemen yang handal. Penelitian berikutnya adalah oleh Padmadi et al. (2016), yang membuat formulasi strategi perusahaan properti di Kota Depok menggunakan matriks IE. Dalam matriks IE posisi perusahaan berada pada sel V (menjaga dan mempertahankan). Strategi yang digunakan adalah penetrasi pasar dan pengembangan produk. Penetrasi pasar dapat dilakukan dengan mengikuti pameran. Pengembangan produk dapat dilakukan dengan inovasi produk hunian yang disukai konsumen. Dwiputra dan Nugraha (2017) membuat suatu formulasi strategi untuk memperbaiki kinerja bisnis pada perusahaan properti milik keluarga. Hasilnya adalah perusahaan dapat melakukan perbaikan kinerja bisnisnya melalui restrukturisasi organisasi. Sapratama (2016) menerapkan tiga strategi utama untuk meningkatkan daya saing Jakarta Garden City yaitu: (1) mengembangkan kawasan yang menggabungkan hunian vertikal, pusat perbelanjaan, perkantoran serta hotel; (2) memperkuat brand image; (3) mengembangkan "eco-smarthome".

Semua penelitian-penelitian tersebut menghasilkan suatu strategi-strategi yang dapat digunakan perusahaan guna menjaga persaingan dengan para kompetitor-kompetitornya. Di Yogyakarta, persaingan dari perusahaan properti sejenis membuat PT XYZ juga harus mempunyai nilai lebih dibanding kompetitor lainnya. Christina dan Sudana (2013) mengatakan bahwa perencanaan strategis pada perusahaan sangat diperlukan jika perusahaan ingin tetap bertahan dalam bisnis yang semakin kompetitif. Berdasarkan latar belakang dan permasalahan yang ada, maka penelitian ini bertujuan untuk mengevaluasi kinerja perusahan sebelum akuisisi hingga saat ini, menganalisis kondisi lingkungan internal dan eksternal PT XYZ pasca akuisisi, serta membuat suatu formulasi strategi untuk memperbaiki kinerjanya.

\section{METODE PENELITIAN}

Jenis data dalam penelitian ini terdiri dari data primer dan sekunder. Data primer diperoleh dari wawancara dan kuisioner. Data sekunder bersumber dari data perusahaan dan studi literatur. Metode penelitian yang digunakan adalah metode diskriptif dengan pendekatan studi kasus. Teknik pengambilan contoh dalam penelitian ini dilakukan dengan pendekatan nonprobability sampling dengan teknik purposive sampling dengan dengan harapan informan yang dipilih memiliki pengetahuan dan pemahaman tentang bisnis apartemen dan kondotel. Informan internal terdiri dari empat orang yang berada di dalam perusahaan. Tiga dari empat orang tersebut merupakan informan yang berada pada posisi manajerial PT XYZ, sedangkan satu orang lagi berasal dari PT ADP. Informan dari PT ADP mereupakan representatif pemegang saham yang memiliki pandangan akan PT XYZ kedepannya. Informan eksternal terdiri dari dua orang yang merupakan perwakilan dari asosiasi pengembang properti dan akademisi. Pandangan dari asosiasi diperlukan untuk mengetahui kondisi bisnis properti secara makro pada saat ini, sedangkan akademisi yang dipilih merupakan informan yang tinggal di 
Kabupaten Sleman, sehingga dapat mengetahui kondisi lingkungan secara detail. Secara lebih rinci, sampel informan yang dipilih dapat dilihat pada Tabel 1.

Tabel 1. Sampel Informan Penelitian

\begin{tabular}{ccl}
\hline Informan & Nama & \multicolumn{1}{c}{ Jabatan } \\
\hline Internal & Agung Hadi Tjahjanto & Direktur Utama PT XYZ \\
Internal & Arif Purbadi & Pimpinan Proyek PT XYZ \\
Internal & Asyikin & Manajer Marketing PT XYZ \\
Internal & Agri Rahadiyan & Direktur Pengembangan Bisnis PT ADP \\
Eksternal & Irwan & Wakil Ketua Umum APERSI \\
Eksternal & Siti Nur Aini & Dosen STTNAS \\
\hline
\end{tabular}

Untuk tahapan pengolahan dan analisis data pada penelitian ini dapat dilihat pada Tabel 2 .

Tabel 2. Tahapan Pengolahan dan Analisis Data

\begin{tabular}{|c|c|c|}
\hline Tujuan & Alat Analisis & Output \\
\hline $\begin{array}{l}\text { Evaluasi kinerja } \\
\text { sebelum akuisisi } \\
\text { hingga saat ini }\end{array}$ & $\begin{array}{l}\text { Fact finding dengan } \\
\text { wawancara dan studi literatur }\end{array}$ & $\begin{array}{l}\text { Faktor-faktor penyebab penurunan } \\
\text { kinerja }\end{array}$ \\
\hline $\begin{array}{ll}\text { - } & \text { Analisis lingkungan } \\
\text { eksternal } \\
\text { - } & \text { Analisis lingkungan } \\
\text { internal } \\
\text { - } & \begin{array}{l}\text { Evaluasi lingkungan } \\
\text { eksternal dan internal }\end{array} \\
\end{array}$ & $\begin{array}{l}\text { PESTLE } \\
\text { Porter's five force } \\
\text { Aspek fungsional perusahaan } \\
\text { Matriks EFE dan IFE }\end{array}$ & $\begin{array}{l}\text { Peluang dan ancaman perusahaan } \\
\text { Kekuatan dan kelemahan perusahaan } \\
\text { Posisi perusahaan saat ini dalam sel } \\
\text { matriks IE }\end{array}$ \\
\hline $\begin{array}{l}\text { - Perumusan strategi } \\
\text { perbaikan kinerja } \\
\text { perusahaan }\end{array}$ & Matriks SWOT & $\begin{array}{l}\text { Strategi-strategi yang dihasilkan untuk } \\
\text { perbaikan kinerja }\end{array}$ \\
\hline
\end{tabular}

Kerangka pemikiran pada penelitian ini dapat dilihat pada Gambar 3. Kerangka pemikiran penelitian ini diawali dengan mengevaluasi kinerja perusahaan sebelum akuisisi hingga saat ini. Evaluasi kinerja tersebut berdasarkan proses fact finding yang didapat dari hasil wawancara maupun literatur perusahaan. Lalu dilakukan evaluasi visi, misi serta strategi yang telah dijalankan. Selanjutnya kajian diperluas dengan menganalisis lingkungan internal dan eksternal. Analisis lingkungan secara eksternal menggunakan metode analisis Porter's Five Forces untuk melihat persaingan antar industri dan metode analisis PESTLE untuk melihat kondisi secara makro. Hasil dari analisis lingkungan internal adalah kekuatan dan kelemahan dari perusahaan, sedangkan hasil analisis lingkungan eksternal menghasilkan peluang dan ancaman bagi perusahaan. Hasil identifikasi isu eksternal maupun internal tersebut dievaluasi menggunakan matriks IFE dan EFE. Kedua matriks tersebut lalu digabungkan menjadi matriks IE. Dalam matriks IE, posisi perusahaan akan ditempatkan pada sebuah sel. Sel tersebut menunjukan langkah yang seharusnya dilakukan dimasa mendatang.

Matriks SWOT digunakan untuk membuat beberapa strategi alternatif yang dapat digunakan oleh perusahaan untuk memperbaiki kinerjanya. Strategi-strategi alternatif tersebut berasal dari kombinasi analisis lingkungan internal dan eksternal yang telah diperoleh. Hasil strategi-strategi yang dihasilkan dalam matriks SWOT dijabarkan kembali dalam sebuah aktivitas kegiatan yang dapat dilakukan. 


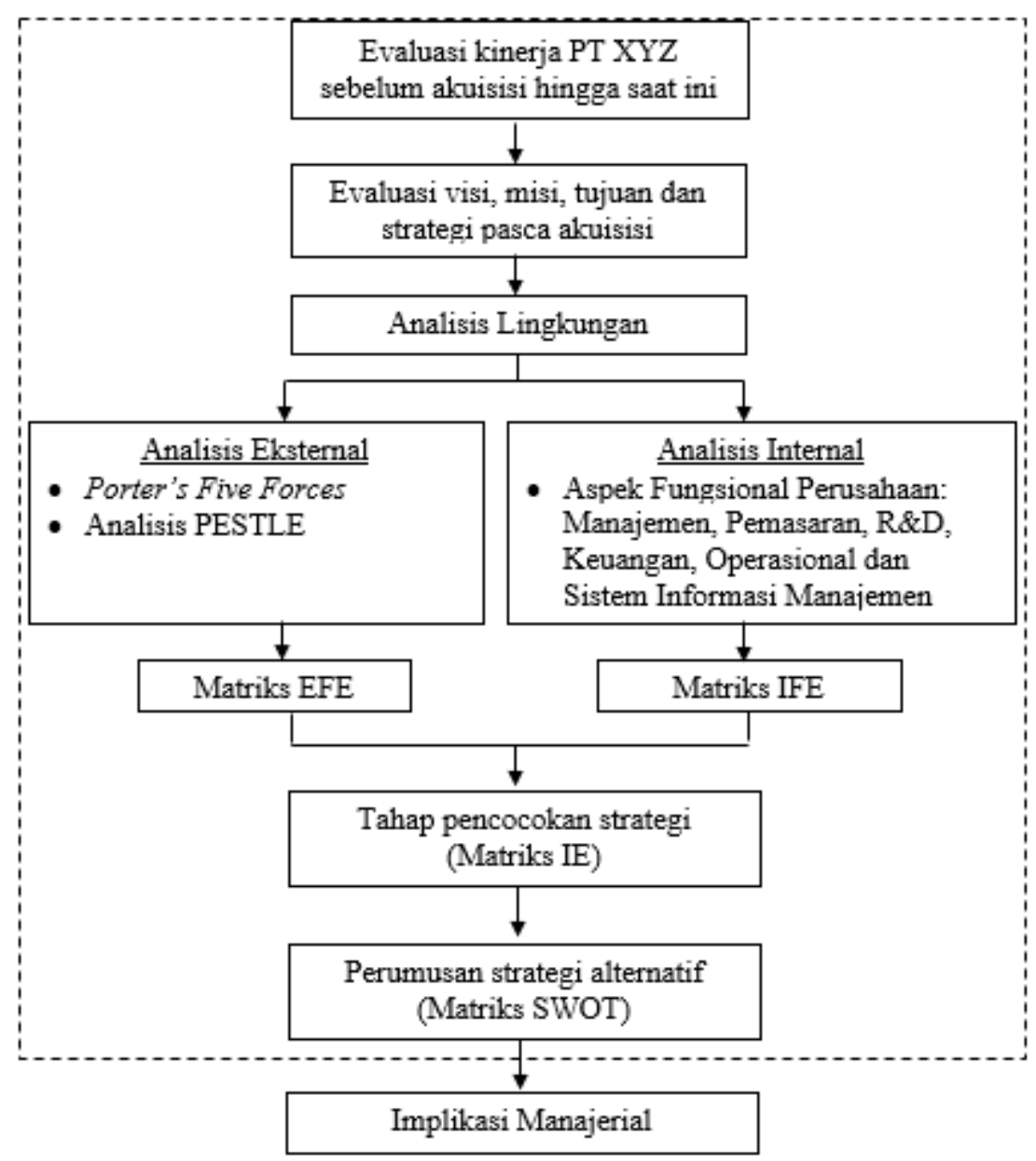

Gambar 3. Kerangka berpikir penelitian

\section{HASIL DAN PEMBAHASAN}

\section{Evaluasi Kinerja Perusahaan}

Evaluasi kinerja dilihat dari tiga aspek, yaitu: progres pembangungan, penjualan dan keuangan perusahaan. Progres pembangunan sebelum akuisisi dilakukan dengan melibatkan kontraktor PT GMJ. Selama 11 bulan, progres yang dilakukan adalah sebesar 2,61 persen. Pada periode pasca akuisisi, perusahaan bekerja sama dengan PT TBR. Selama enam bulan, PT TBR berhasil memberikan progres 13,39 persen. Hasil evaluasi tersebut menunjukan bahwa PT GMJ wanprestasi. Kesalahan manajemen PT XYZ dalam memilih kontraktor yang handal menyebabkan pembangunan terhambat. Hal tersebut sesuai dengan penelitian yang dilakukan Koushki et al. (2005) yang menyatakan bahwa kurangnya pengalaman pengembang menyebabkan mundurnya waktu penyelesaian proyek.

Progres penjualan apartemen dan kondotel sebelum akuisisi (Oktober 2013 - Oktober 2017) adalah sebanyak 217 unit. Pasca akuisisi perusahaan hanya berhasil menjual satu unit. Dari total 218 unit, terdapat 100 konsumen yang membatalkan unit sehingga tersisa 118. Kesulitan yang dialami manajemen saat ini diakui akibat harga unit yang overpriced akibat kenaikan sebesar 56 persen pada tahun 2014, namun tidak diiringi oleh kemajuan pembangunan yang signifikan. Grafik kenaikan harga dapat dilihat pada Gambar 4. 


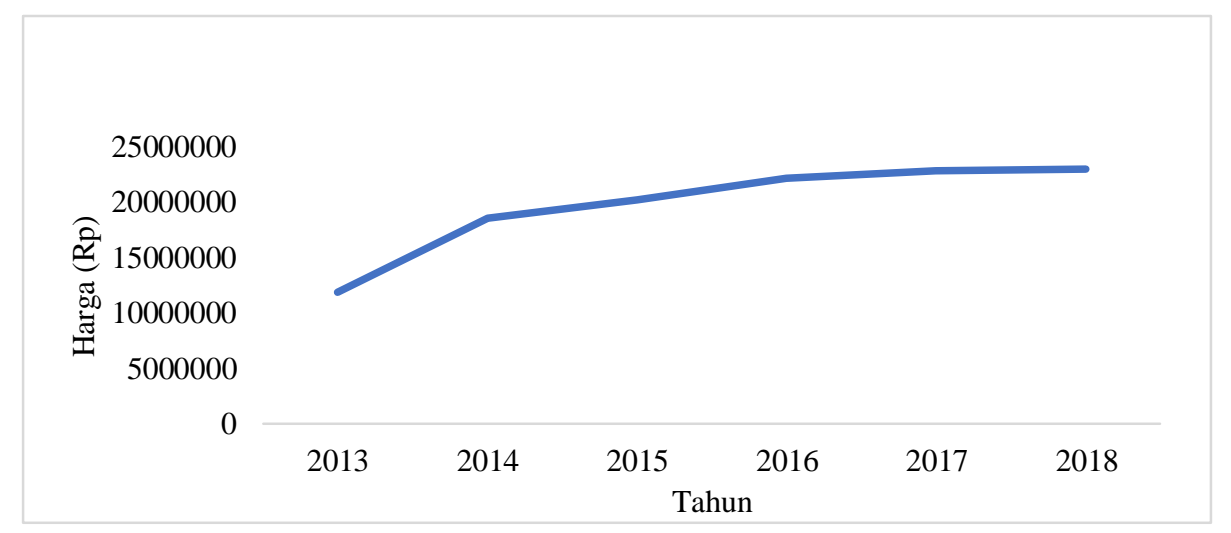

Gambar 4. Grafik Kenaikan Harga Apartemen Tahun 2013 - 2018

Dari sisi keuangan, keputusan manajemen untuk mencantumkan garansi 100 persen dana kembali dalam PPJB (Perjanjian Pengikatan Jual Beli) jika pembangunan belum selesai, membawa dampak pada keuangan perusahaan. Ekuitas yang dimiliki perusahaan menurun akibat banyaknya konsumen yang membatalkan unit. Hingga akhir 2017, hutang perusahaan meningkat dari tahun sebelumnya. Hal ini terlihat dari perhitungan rasio keuangan debt to equity ratio (DER). Pada tahun 2015-2017, nilai DER yang dihasilkan adalah 1,57; 2,04; dan 6,44. Pada tahun 2017, nilai hutang perusahaan menjadi tiga kali lebih besar dari tahun sebelumnya.

\section{Analisis Lingkungan Eksternal}

Hasil analisis lingkungan eksternal mendapatkan tujuh peluang dan tujuh ancaman yang dihadapi oleh perusahaan saat ini. Peluang dan ancaman tersebut lalu dievaluasi menggunakan matriks EFE untuk melihat respon perusahaan saat ini terhadap faktor-faktor tersebut. Matriks EFE PT XYZ dapat dilihat pada Tabel 4.

Tabel 4. Matriks EFE PT XYZ

\begin{tabular}{|c|c|c|c|}
\hline Peluang & Bobot & Rating & Skor \\
\hline $\begin{array}{l}\text { Kebijakan BI tentang Loan to Value (LTV) sebesar } 90 \% \text { untuk } \\
\text { kepemilikan apartemen pertama }\end{array}$ & 0,07 & 2 & 0,14 \\
\hline $\begin{array}{l}\text { Moratorium izin pendirian hotel, apartemen dan kondotel baru di } \\
\text { Wilayah Kabupaten Sleman hingga } 31 \text { Desember } 2021\end{array}$ & 0,08 & 3 & 0,24 \\
\hline Daya konsumsi masyarakat pada Triwulan I tahun 2018 sebesar 5,06\% & 0,05 & 2 & 0,10 \\
\hline Jumlah penduduk Provinsi DIY yang selalu tumbuh tiap tahunnya & 0,05 & 2 & 0,10 \\
\hline Perkembangan teknologi informasi dan social media & 0,08 & 4 & 0,32 \\
\hline $\begin{array}{l}\text { Lokasi apartemen dan kondotel terletak diantara } 2 \text { kampus besar (UGM } \\
\text { dan UII) }\end{array}$ & 0,09 & 4 & 0,36 \\
\hline Daya tarik objek wisata di Provinsi DIY & 0,07 & 4 & 0,28 \\
\hline \multicolumn{4}{|l|}{ Ancaman } \\
\hline Iklim politik di Indonesia & 0,06 & 3 & 0,18 \\
\hline Kenaikan tingkat suku bunga BI menjadi 4,75\% (periode 30 Mei 2018) & 0,05 & 2 & 0,10 \\
\hline Keinginan untuk membatalkan pembelian unit oleh konsumen lama & 0,09 & 3 & 0,27 \\
\hline Status aktif Gunung Merapi & 0,07 & 2 & 0,14 \\
\hline Harga jual para pesaing dibawah harga jual PT XYZ & 0,08 & 3 & 0,24 \\
\hline Kekuatan nama besar developer pesaing & 0,07 & 4 & 0,28 \\
\hline Mudahnya konsumen beralih ke apartemen lain & 0,07 & 3 & 0,21 \\
\hline Total & & & 2,96 \\
\hline
\end{tabular}

Analisis lingkungan eksternal perusahaan menunjukan bahwa perusahaan sudah dapat

merespon dengan baik peluang yang ada, baik perkembangan teknologi informasi dan sosial media, lokasi apartemen dan kondotel yang terletak di antara kampus UGM dan UII, serta banyaknya daya tarik objek wisata di Provinsi DIY. Hal tersebut ditunjukan dengan nilai rating empat yang diperoleh. Namun dari segi tingkat kepentingan, dengan nilai bobot 0,09 , peluang 
yang menjadi prioritas kepentingan adalah lokasi apartemen yang terletak diantara dua kampus besar (UGM dan UII).

Dari segi ancaman, dengan nilai bobot 0,09 pada faktor keinginan konsumen lama untuk membatalkan pembelian unit menjadi prioritas kepentingan yang sudah dapat direspon oleh perusahaan. Sedangkan nilai rating empat pada kekuatan nama besar developer pesaing menunjukan bahwa perusahaan telah mampu meredam nama besar developer yang menjadi pesaing. Evaluasi matriks EFE memiliki nilai 2,96. Skor tersebut lebih besar dari nilai rata-rata $(2,50)$ menunjukan bahwa perusahaan saat ini cukup mampu untuk merespon peluang dan ancaman yang ada.

\section{Analisis Lingkungan Internal}

Hasil analisis lingkungan internal mendapatkan delapan kekuatan dan tujuh kelemahan yang dimiliki oleh perusahaan saat ini. Kekuatan dan kelemahan tersebut lalu dievaluasi menggunakan matriks IFE untuk mengukur seberapa besar kondisi internal perusahaan baik dari sisi kekuatan maupun kelemahan. Matriks IFE PT XYZ dapat dilihat pada Tabel 5.

Tabel 5. Matriks IFE PT XYZ

\begin{tabular}{llll}
\multicolumn{1}{c}{ Kekuatan } & Bobot & Rating & Skor \\
\hline $\begin{array}{l}\text { Perubahan struktur organisasi perusahaan sudah cukup tepat dan } \\
\text { berjalan dengan baik }\end{array}$ & 0,08 & 3 & 0,24 \\
\hline Komitmen BOD dan BOC dalam pertumbuhan perusahaan & 0,08 & 3 & 0,24 \\
\hline Dibentuknya collection group & 0,07 & 3 & 0,21 \\
\hline Penerapan strategi pemasaran secara online dan offline & 0,08 & 3 & 0,24 \\
\hline Menggunakan kontraktor yang berpengalaman (PT Tata Bumi Raya) & 0,09 & 4 & 0,36 \\
\hline $\begin{array}{l}\text { Kesepakatan kerjasama pengelolaan kondotel dengan PT Golden } \\
\text { Tulip Hospitality Management Indonesia }\end{array}$ & 0,05 & 3 & 0,15 \\
\hline Pembelian teknologi baru $\quad$ Kelemahan & 0,04 & 3 & 0,12 \\
\hline Berlanjutnya pencairan dana pinjaman dari BTN Syariah & 0,08 & 4 & 0,32 \\
\hline & & 1 & 0,04 \\
\hline $\begin{array}{l}\text { Belum ada program pelatihan dan pengembangan karyawan yang } \\
\text { terencana }\end{array}$ & 0,04 & 0,14 \\
\hline Lemahnya kekuatan perusahaan terhadap PPJB konsumen lama & 0,07 & 2 & 0,10 \\
\hline Progres pembangunan baru sebesar 16\% (Hingga Mei 2018) & 0,05 & 2 & 0,06 \\
\hline Materi promosi kurang bervariasi & 0,06 & 1 & 0,07 \\
\hline Target penjualan unit para sales belum tercapai & 0,07 & 1 & 0,07 \\
\hline Strategi penetapan harga yang terlalu tinggi & 0,07 & 1 & 0,14 \\
\hline Pilihan pembayaran yang kurang flexible & 0,07 & 2 & 2,50 \\
\hline Total & & & \\
\hline
\end{tabular}

Hasil evaluasi matriks internal menunjukan bahwa kekuatan terpenting yang miliki oleh perusahaan saat ini adalah kerjasama dengan kontraktor PT Tata Bumi Raya (PT TBR) yang sudah berpengalaman dan berlanjutnya pencairan dana dari BTN Syariah. Kekuatan tersebut mendapatkan rating empat. Dari segi kepentingan, kerjasama dengan kontraktor PT Tata Bumi Raya menjadi kekuatan yang paling penting bagi perusahaan. Hal ini terlihat dari nilai bobot yang diperoleh, yaitu 0,09 .

Dari segi kelemahan, perusahaan sangat lemah dalam program pelatihan dan pengembangan karyawan, materi promosi, target penjualan unit para karyawan sales serta strategi penetapan harga. Hal tersebut ditunjukan dengan nilai rating satu yang diperoleh. Sedangkan berdasarkan kepentingannya, dengan nilai bobot 0,07 yang diperoleh, kelemahan perusahaan yang harus segera diperbaiki yaitu lemahnya kekuatan perusahaan terhadap PPJB konsumen lama, target penjualan unit para sales yang belum tercapai, strategi penetapan harga yang terlalu tinggi, serta pemilihan pembayaran yang kurang flexible. Evaluasi matriks IFE memiliki nilai 2,5 menunjukan bahwa internal perusahaan berada pada posisi rata-rata $(2,5)$, artinya perusahaan tidak terlalu kuat maupun tidak terlalu lemah. 


\section{Analisis Matriks IE}

Berdasarkan nilai EFE dan IFE sebesar 2,96 dan 2,50, posisi perusahaan berada pada sel $\mathrm{V}$ (menjaga dan mempertahankan) seperti yang dapat dilihat pada Gambar 5.

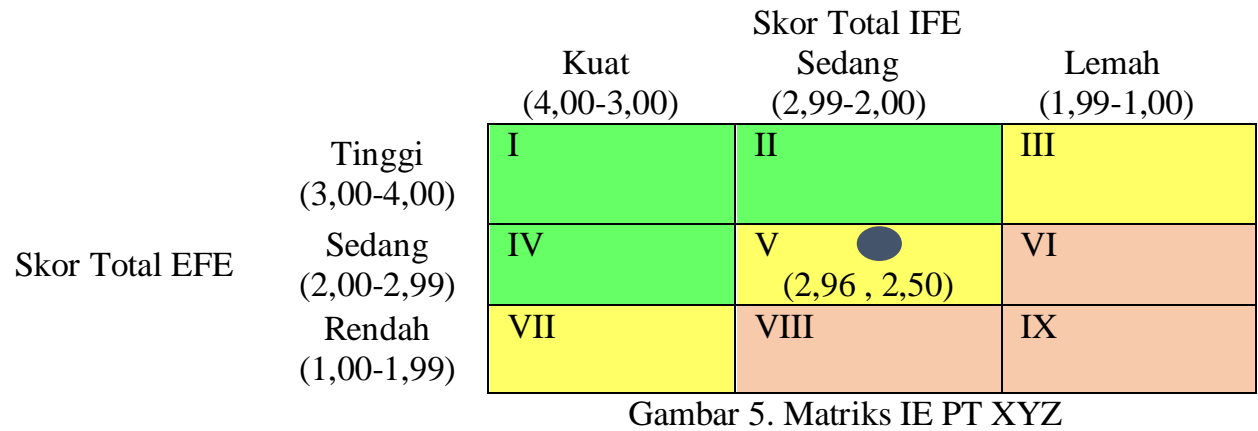

Menurut David (2011), implikasi strategi yang dapat digunakan posisi tersebut adalah strategi penetrasi pasar dan pengembangan produk.

\section{Analisis SWOT}

Analisis SWOT digunakan untuk mencari strategi-strategi alternatif. Analisis SWOT dilakukan dengan bantuan matriks SWOT. Hasil perumusan strategi alternatif menggunakan matriks SWOT tersebut dapat dilihat pada Gambar 6. 


\begin{tabular}{|c|c|c|}
\hline & $\underline{\text { Kekuatan }(\mathrm{S})}$ & Kelemahan (W) \\
\hline Faktor Eksternal & $\begin{array}{l}\text { 1. Perubahan struktur organisasi } \\
\text { perusahaan sudah cukup tepat dan } \\
\text { berjalan dengan baik } \\
\text { 2. Komitmen BOD dan BOC dalam } \\
\text { pertumbuhan perusahaan } \\
\text { 3. Dibentuknya collection group } \\
\text { 4. Penerapan strategi pemasaran } \\
\text { secara online dan offline } \\
\text { 5. Menggunakan kontraktor yang } \\
\text { berpengalaman (PT Tata Bumi } \\
\text { Raya) } \\
\text { 6. Kesepakatan kerjasama } \\
\text { pengelolaan kondotel dengan PT } \\
\text { Golden Tulip Hospitality } \\
\text { Management Indonesia } \\
\text { 7. Pembelian teknologi baru } \\
\text { 8. Berlanjutnya pencairan dana } \\
\text { pinjaman dari BTN Syariah }\end{array}$ & $\begin{array}{l}\text { 1. Belum ada program } \\
\text { pelatihan dan } \\
\text { pengembangan karyawan } \\
\text { yang terencana } \\
\text { 2. Lemahnya kekuatan } \\
\text { perusahaan terhadap PPJB } \\
\text { konsumen lama } \\
\text { 3. Progres pembangunan baru } \\
\text { sebesar 16\% (Hingga Mei } \\
\text { 2018) kurang } \\
\text { 4. Materi promosi } \\
\text { bervariasi } \\
\text { 5. Target penjualan unit para } \\
\text { sales belum tercapai } \\
\text { 6. Strategi penetapan harga } \\
\text { yang terlalu tinggi } \\
\text { 7. Pilihan pembayaran yang } \\
\text { kurang flexible }\end{array}$ \\
\hline $\begin{array}{l}\text { Peluang (O) } \\
\text { 1. Kebijakan BI tentang Loan to Value } \\
\text { (LTV) sebesar 90\% untuk kepemilikan } \\
\text { apartemen pertama } \\
\text { 2. Moratorium izin pendirian hotel, } \\
\text { apartemen dan kondotel baru di } \\
\text { Wilayah Kabupaten Sleman hingga } 31 \\
\text { Desember 2021 } \\
\text { 3. Daya konsumsi masyarakat pada } \\
\text { Triwulan I tahun 2018 sebesar 5,06\% } \\
\text { 4. Jumlah penduduk Provinsi DIY yang } \\
\text { selalu tumbuh tiap tahunnya } \\
\text { 5. Perkembangan teknologi informasi dan } \\
\text { social media } \\
\text { 6. Lokasi apartemen dan kondotel } \\
\text { terletak diantara } 2 \text { kampus besar } \\
\text { (UGM dan UII) } \\
\text { 7. Daya tarik objek wisata di Provinsi } \\
\text { DIY }\end{array}$ & $\begin{array}{l}\text { Strategi SO } \\
\text { 1. Meningkatkan aktivitas promosi } \\
\text { dan penjualan (S1, S4, S5, S6, S8, } \\
\text { O1, O2, O4, O5, O6, O7) }\end{array}$ & $\begin{array}{l}\text { Strategi WO } \\
\text { 1. Meningkatkan hubungan } \\
\text { baik dengan para konsumen } \\
\text { (W2, W3, O4, O5) } \\
\text { 2. Merekrut karyawan sales } \\
\text { berpengalaman (W1, W5, } \\
\text { O4) }\end{array}$ \\
\hline $\begin{array}{l}\text { Ancaman (T) } \\
\text { 1. Iklim politik di Indonesia } \\
\text { 2. Kenaikan tingkat suku bunga BI } \\
\text { menjadi 4,75\% (periode } 30 \text { Mei 2018) } \\
\text { 3. Keinginan untuk membatalkan } \\
\text { pembelian unit oleh konsumen lama } \\
\text { 4. Status aktif Gunung Merapi } \\
\text { 5. Harga jual para pesaing dibawah harga } \\
\text { jual PT XYZ } \\
\text { 6. Kekuatan nama besar developer } \\
\text { pesaing ke } \\
\text { 7. Mudahnya konsumen beralih ke } \\
\text { apartemen lain }\end{array}$ & $\begin{array}{l}\text { Strategi ST } \\
\text { 1. Rebranding nama apartemen dan } \\
\text { kondotel (S1, S2, S8, T3, T6, T7) }\end{array}$ & $\begin{array}{l}\text { Strategi WT } \\
\text { 1. Membuat nilai tambah } \\
\text { apartemen yang dijual (W6, } \\
\text { T5, T6) }\end{array}$ \\
\hline
\end{tabular}

Gambar 6. Matriks SWOT PT XYZ 


\section{Strategi SO}

Strategi SO yang dihasilkan oleh matriks SWOT adalah meningkatkan aktivitas promosi dan penjualan. Strategi ini merupakan strategi besar yang dapat dijabarkan menjadi lima aktivitas strategi yang dapat dijalankan seperti: (1) membuat materi promosi yang variatif dengan memanfaatkan program LTV (DP 10 persen) dan materi promosi yang menonjolkan spesifikasi bangunan yang sedang dibangun serta interior yang akan didapatkan saat pembelian kondotel; (2) membangun kerja sama dengan agen-agen properti serta kerja sama dengan kampus-kampus ternama seperti UII dan UGM guna mencari calon konsumen potensial; (3) meningkatkan frekuensi pemasaran secara online baik memanfaatkan social media seperti instagram, facebook maupun twitter, serta pemanfaatan SMS/WA blast secara rutin; (4) meningkatkan frekuensi pemasaran secara offline melalui media massa, billboard, brosur dan flayer dengan konten-konten yang menarik; (5) mengikuti aktivitas pameran yang diadakan di kota-kota besar guna menjaring konsumen yang berminat untuk berinvestasi di Yogyakarta. Aktivitas pameran ini sejalan dengan strategi penetrasi pasar yang dijalankan oleh Lesmana (2016) dalam upaya meningkatkan penjualan.

\section{Strategi WO}

Strategi WO yang dihasilkan oleh matriks SWOT adalah meningkatkan hubungan baik dengan konsumen. Salah satu cara meningkatkan hubungan baik tersebut adalah dengan menerapkan Costumer Relationship Management (CRM). Penerapan CRM dapat mengetahui konsumen dengan baik sehingga perusahaan dapat menyediakan layanan yang efisien untuk menjaga konsumen selamanya (Chittaie, 2012). Ada tiga aktivitas yang dapat dilakukan seperti: (1) membentuk divisi Costumer Relation; (2) mengadakan gathering-gathering pada momenmomen tertentu seperti momen ketika bangunan sudah topping-off dan selesai 100 persen; (3) memberikan informasi progres pembangunan setiap bulannya melalui divisi Costumer Relation yang sudah terbentuk.

Selain meningkatkan hubungan baik dengan konsumen, strategi lain yang dihasilkan adalah merekrut karyawan sales berpengalaman. Kondisi penjualan unit oleh para sales yang tidak tercapai membuat perusahaan harus mengevaluasi kinerja para sales tersebut. Tidak adanya pelatihan dan pengembangan untuk karyawan sales saat ini merupakan salah satu kelemahan perusahaan. Namun pelatihan dan pengembangan pun tidak dapat dilaksanakan dalam waktu yang cepat, perlu dilihat skill apa yang sekiranya perlu dikembangkan. Oleh karena itu, solusi tercepat yang dapat digunakan oleh perusahaan adalah merekrut karyawan baru yang sudah berpengalaman. Harapannya dengan adanya karyawan tersebut, target penjualan unit mampu untuk dicapai. Selain itu karyawan berpengalaman tersebut dapat berbagi ilmu yang telah diperolehnya dengan karyawan-karyawan sales lain. Tahapan persiapan yang dapat dilakukan oleh perusahaan sebelum merekrut karyawan sales berpengalaman tersebut antara lain: (1) membuat requirement karyawan sales yang dibutuhkan; (2) mencari karyawan sales baru tersebut di social media seperti linkedin. (3) proses rekrutmen karyawan sales terpilih.

\section{Strategi ST}

Strategi ST yang dihasilkan oleh matriks SWOT adalah rebranding nama apartemen dan kondotel. Terdapat dua rencana kegiatan yaitu menggunakan nama baru apartemen dan kondotel pada setiap konten pemasaran dan mengikutsertakan nama "Agung Development Properti Group" pada setiap promosi. Strategi ini bertujuan untuk menunjukan bahwa brand image setelah akuisisi menjadi lebih baik. Sesuai dengan pernyataan Susi (2012) dalam penelitiannya mengungkapkan bahwa menciptakan brand image yang baik adalah salah satu strategi yang dapat digunakan untuk bersaing dengan para kompetitor.

\section{Strategi WT}

Strategi WT yang dihasilkan oleh matriks SWOT adalah membuat nilai tambah 
peralatan elektronik rumah tangga yang dimilikinya (Masykur \& Prasetiyowati, 2016). Strategi ini dimulai dengan pemilihan vendor hingga pemasangan teknologi "smart home" tersebut.

\section{Implikasi Manajerial}

Implikasi manajerial dari penelitian ini diwujudkan dalam suatu formulasi strategi. Formulasi strategi tersebut dijabarkan kedalam rencana kegiatan strategik dalam jangka waktu empat tahun (2019-2022). Rencana kegiatan strategik tersebut dibangun berdasarkan lima alternatif strategi hasil matriks SWOT. Urutan prioritas strategi yang akan dijalankan oleh perusahaan ditentukan berdasarkan interview terhadap direktur utama.

Dari kelima alternatif strategi tersebut, strategi prioritas pertama adalah rebranding nama apartemen dan kondotel. Strategi tersebut akan mulai dibahas di jajaran direksi pada bulan Januari 2019. Pada bulan Februari 2019, semua konten pemasaran sudah dapat diganti dengan nama baru yang telah disepakati. Prioritas strategi kedua adalah meningkatkan aktivitas promosi dan penjualan. Aktivitas membangun kerja sama dengan agen dan kampus UGM dan UII dimulai pada bulan Februari 2019. Membuat materi promosi yang variatif hingga meningkatkan frekuensi pemasaran secara online maupun offline dilaksanakan secara periodik hingga tahun 2022. Prioritas strategi ketiga adalah meningkatkan hubungan baik dengan konsumen. Pembentukan divisi Costumer Relation dilaksanakan pada bulan Maret 2019. Informasi perkembangan pembangunan disampaikan setiap bulan hingga Januari 2020 setelah bangunan selesai. Gathering dengan konsumen diadakan setiap bulan Desember 2019 hingga 2022. Prioritas strategi keempat adalah membuat nilai tambah apartemen yang dijual dengan konsep "smart home". Persiapan pemilihan vendor dimulai bulan April 2019. Pemasangan teknologi "smart home" itu sendiri dilaksanakan pada bulan Juli hingga Desember 2019. Prioritas strategi kelima adalah merekrut karyawan sales berpengalaman. Strategi ini menjadi prioritas terakhir karena manajemen ingin melihat dampak yang dihasilkan dari keempat strategi sebelumnya. Tahapan perekrutan karyawan sales berpengalaman dimulai pada bulan Januari hingga Maret 2020.

\section{KESIMPULAN}

Kesimpulan yang ditarik dari penelitian ini adalah sebagai berikut: (1) Faktor yang menyebabkan kinerja perusahaan menurun disebabkan oleh aspek pengambilan keputusan oleh para manajemen sebelum perusahaan diakuisisi. Tercatat beberapa keputusan yang membuat buruknya kinerja perusahaan seperti keputusan dalam memilih kontraktor, strategi penetapan harga, serta keputusan mencantumkan garansi 100 persen dana kembali dalam PPJB jika konsumen membatalkan unit. (2) Kondisi lingkungan internal dan eksternal perusahaan setelah proses akuisisi berada pada sel V (menjaga dan mempertahankan) dengan skor IFE sebesar 2,5 dan skor EFE sebesar 2,96. Kekuatan utama perusahaan adalah penggunaan kontraktor PT Tata Bumi Raya (PT TBR) yang memperoleh skor 0,36. Kelemahan yang belum dapat ditangani dengan baik oleh perusahaan adalah belum adanya pelatihan dan pengembangan karyawan dengan skor 0,04. Dari sisi eksternal, perusahaan sudah dapat merespon dengan baik perkembangan teknologi informasi dan social media, lokasi apartemen dan kondotel yang terletak di antara kampus UGM dan UII serta banyaknya daya tarik objek wisata di Provinsi DIY. (3) Alternatif strategi yang dihasilkan matriks SWOT menghasilkan 5 strategi besar yaitu: 1) rebranding nama apartemen dan kondotel; 2) meningkatkan aktivitas promosi dan penjualan; 3) meningkatkan hubungan baik dengan konsumen; 4) membuat nilai tambah apartemen yang dijual; 5) merekrut karyawan sales berpengalaman. Formulasi perbaikan kinerja perusahaan disusun berdasarkan 5 (lima) strategi yang sudah dibangun berupa rencana kegiatan strategik dan waktu pelaksanaan kegiatan selama empat tahun (2019-2022).

Beberapa hal yang dapat disampaikan sebagai saran kepada manajemen PT XYZ untuk memperbaiki kinerjanya, yaitu perusahaan harus memperbaiki citra buruk yang melekat pada perusahaan sebelum akuisisi dengan cara rebranding nama apartemen dan kondotel. Setelah nama baru diputuskan, perusahaan dapat meningkatkan kegiatan pemasaran dan promosi menggunakan nama baru tersebut. Selain itu, pendekatan personal dengan konsumen lama juga 
perlu dilakukan guna tetap menjaga kepercayaan mereka terhadap perusahaan. Dari sisi penetapan harga yang tinggi, perusahaan dapat membuat nilai tambah dari produk yang dijual. Dengan mengimplementasikan strategi-strategi tersebut diharapkan kinerja perusahaan pasca akuisisi dapat membaik.

\section{DAFTAR PUSTAKA}

[BPS] Badan Pusat Statistik. 2017. Provinsi Daerah Istimewa Yogyakarta Dalam Angka. Yogyakarta: UD Sinar Baru Offset Yogyakarta.

Chittaie, R. (2012). Costumer relationship management and business strategies. International Journal of Organizational Leadership, 1(1), 13-22.

Christina, N. P. Y., \& Sudana, I. P. (2013). Penilaian kinerja pada PT Adhi Karya dengan pendekatan balanced scorecard. E-Jurnal Akuntansi Universitas Udayana, 5(3), 516-529.

David, F. R. (2011) (13 ${ }^{\text {th }}$ Ed). Strategic Management: Concepts and Cases. New Jersey: Prentice Hall.

Devi, Y. S. (2012). Analisis strategi bersaing rusunami kalibata city. Jakarta: Universitas Indonesia.

Dwiputra, \& Nugraha. (2017). Formulasi strategi untuk perbaikan kinerja bisnis pada perusahaan properti milik keluarga (Studi kasus: PT XYZ). Bogor: Institut Pertanian Bogor.

Hashim, M. K. (2016). Approaches to formulating business strategy. Arabian Journal of Business and Management, 7(1), 1-7.

Koushki, P. A., Al-Rashid, K. \& Kartam, N. (2005). Delays and cost increases in the construction of private residential projects in Kuwait. Construction Management and Economics, 23(3), 285-294.

Lesmana, R. (2016). Strategi pemasaran untuk meningkatkan penjualan perumahan di green river city (studi kasus di PT Artha bangun Pratama). Jurnal Ilmiah Ilmu Manajemen, 3(2), 40-59.

Masykur, F., \& Prasetiyowati, F. (2016). Aplikasi rumah pintar (smart home pengendali peralatan elektronik rumah tangga berbasis web. Jurnal Teknologi Informasi dan Ilmu Komputer, 3(1), 51-58.

Padmadi, B., Syarief R., \& Yusuf A. M. (2016). Strategic formulation of PT Triasta Putra Santika facing housing growth in Depok. International Journal of Scientific and Research Publications, 6(7), 44-51.

Sapraptama, R. M. E. (2016). Strategi bisnis untuk meningkatkan daya saing township Jakarta Garden City. Jurnal Bisnis dan Manajemen, 52(11), 245-269.

Suryati. (2010). Strategi akuisisi dan restrukturisasi. Jurnal Mimbar Bumi Bengawan, 3(6), 113.

Susi, T. (2012). Kajian strategi marketing the peak at Sudirman. Jurnal Perspektif Arsitektur, 7(2), 44-50.

Wulandari, R., Fahmi, I., \& Nurmalina, R. (2017). Perencanaan strategis dengan pendekatan balance scorecard pada perusahaan properti (studi kasus: Elang Group). Jurnal Aplikasi Bisnis dan Manajemen, 3(2), 299-312. 